Original Research

\title{
The Art of (Up)Recycling: How Plastic Debris Has Become a Matter of Art?
}

Marianna Michałowska *

Adam Mickiewicz University in Poznań 1. Ul. Wieniawskiego 1, 61-712 Poznań, Poland; E-Mail: mariamne@amu.edu.pl

* Correspondence: Marianna Michałowska; E-Mail: mariamne@amu.edu.pl

Academic Editor: Zed Rengel

Adv Environ Eng Res

2021, volume 2, issue 4

doi:10.21926/aeer.2104025
Received: June 11, 2021

Accepted: October 07, 2021

Published: October 18, 2021

\begin{abstract}
Since 1907, when Bakelite was invented, there has been a dramatic rise in the daily usage of plastic-like materials. Today, its negative impacts are a part of scientific studies and public debates. Art and artists play a significant role in these discussions. They mediate between the specialist content and public awareness. This study is dedicated to the artworks of artists using plastic waste collected from the seashore. I organized their works into three lines, within which artists have different threads of plastic interference in the natural environment. The artists examine: 1 . The future of a planet dominated by plastic products, like Bonita Ely's work from the Plasticus Progressus series that predict post-human existence. 2. The conceptual metaphors of contemporary culture, presented in Bounty, Pilfered by Pam Longobardi. It is an installation constructed from fishing debris. 3. The "nature-cultural" forms, i.e., organic constructions created by human interference and modified by nature, like Crochet Coral Reefs. The cooperation of volunteers with Margaret and Christine Wertheim produced this artwork. The artistic intervention creates new cultural and natural forms. This kind of artistic attitude towards waste is a formal and aesthetic innovation of various materials used in artistic practices. It also makes a significant commentary about the future of Earth. In a discussion about art producing unnecessary objects, recycling artistic material seems more ethical than using non-renewable materials obtained from natural sources.
\end{abstract}

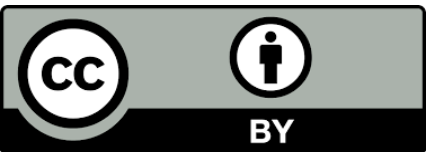

(C) 2020 by the author. This is an open access article distributed under the conditions of the Creative Commons by Attribution License, which permits unrestricted use, distribution, and reproduction in any medium or format, provided the original work is correctly cited. 


\section{Keywords}

Environmental art; plastic debris; anthropocene; natureculture; Bonita Ely; Pam Longobardi; Margaret; Christine Wertheim

\section{Introduction}

Depleting natural resources encourage innovative research on the combination of science and art. While natural scientists look for better renewable energy sources to counteract the consequences of climate change, designers seek methods to reuse waste materials, and artists reflect on their artwork. In the Anthropocene Epoch, is it still ethical to create artworks using natural resources like stone and metal? How to deal with the negative impacts of modern progress regarding landfills, sewage, and especially plastic?

The omnipresence of plastic in the natural environment is no longer a research topic for oceanographers and microbiologists [1]. It is now one of the main subjects of discourse in philosophy [2-5], design [6, 7] and art-activism [8-11]. ${ }^{1}$ Art theorist Monika Bakke compares the spread of plastic to a pandemic, given its global circulation. She emphasizes that plastic and microplastics are present everywhere on Earth. Its production is constantly increasing (Bakke writes about the annual production of almost 300 million tons of plastic) whereas, only $20 \%$ goes for recycling [13].

The sea and ocean currents influence the circulation of plastic by dispersing its harmful leftover products worldwide. Plastic waste is also a metaphor for economic and social relations. Gillian Whiteley writes that "Waste is, of course, an adjunct of luxury. Junk, trash, garbage, rubbish, refuse, whatever we call it, is dependent on economic wealth and excess production ". Garbage also becomes "the ideal postmodern and postcolonial metaphor" that shows the interdependencies of developed and marginalized societies ([7], p.135). Wealthy societies use plastic products. At the first sale, they constantly produce new items and dump them quickly. The latter is dependent on its segregation and recycling, accepting waste, and raising funds for survival and recovery of hazardous substances from landfills.

Artists observe these processes closely, and their artistic and cultural activities highly focus on the impact and awareness about garbage on the planet. They assign new tasks to art that includes generating awareness about the global and local impacts of pollution. They inspire the community to act for the Earth's protection and proper sewage treatment. This approach corresponds to artistic trends of the 20th century, including environmental art, upcycled art, "sustainable design" and "eco-aesthetics". The use of plastic in art also introduces new topics to the discourse of museology and conservation. It addresses the issues of durability and storage of objects in museums and collections [6].

This article presents the works of artists who collected and used plastic waste, from the seashores and oceans, for their works. We focus on three aspects of their artworks- a story about

\footnotetext{
${ }^{1}$ The pollution of the oceans with plastic has also become the subject of comprehensive, interdisciplinary research, such as a global analysis titled "Breaking the Plastic Wave", developed by an international team of researchers, including from Oxford University and University of Leeds for The Pew Charitable Trust [12].
} 
the planet's future, a metaphor for the state of contemporary culture, and a "natural-cultural alliance" ([13], p.139) where natural and plastic substances produce new objects. The presented art pieces provoke questions about the origin of the artist and art while discussing climate change and the effectiveness of such artistic argumentation. Can art convince audiences to work against the effects of the Anthropocene, or is it using waste to enhance the exclusivity of museums in a wealthy world?

\section{Materials and Methods}

\subsection{Plastic as a Matter of Art in the $20^{\text {th }}$ and $21^{\text {st }}$ Century}

Plastic has been used in artistic activities since its invention ${ }^{2}$ in the early $20^{\text {th }}$ century. Initially, it was one of the several types of waste used for creating artwork. In an avant-garde practice, with other components of garbage, plastic indicated modernity. It fascinated others with its progress, industry, and discoveries in chemistry, physics, and engineering. The particular cultural meaning connoted by the rubbish varied according to artistic movements using it. Plastic waste became an artistic material similar to other organic and inorganic substances like glass, sand, or outdated newspapers (e.g., in the paintings of Georges Braque or the Large Glass by Marcel Duchamp).

The artists used trash to introduce the theme of "raw reality" into art and break its symbolic and metaphysical character. According to the philosopher Walter Benjamin, "derelict objects could offer a radical critique of history's myth of universal Progress". Although the historian and art critic is compared to a rag picker $([2,14]$, p.63), he creates bizarre collections and new constellations of reality [3].

The socio-cultural importance of waste in art has evolved. In Dadaistic Objets Trouvés, the waste questions the bourgeois values of art and its social status, while in surreal terms, waste and bulk-produced objects wake our subconscious by their association (examples are here the works by Duchamp, Man Ray, Méret Oppenheim, André Breton, and Max Ernst). In Kurt Schwitters and Vladimir Tatlin's art, the exhibition of trash questions the place of art in social systems. Waste allows artists to comment on the modernity born of revolution and war.

Rubbish gets a different meaning from the art creators of the 1950s and 1960s. The name 'junk art' was coined by Lawrence Alloway in 1961 during the exhibition "The Art of Assemblage" at MoMA $[13,15,16]$. It expressed the need to redefine the arts. The participants of this great review of "junk art", for example, Daniel Spoerri, Allan Kaprow, or Alfonso Ossorio were the "bricoleur" artists. They opposed the image of autotelic and autonomous modernist art with action-oriented and participatory projects.

The contemporary approach to waste and rubbish reveals the evolution of the humanities, which moves from anthropocentric to post-humanist concepts. The works of the surrealists and even the anarchistic bricoleurs of the 1960s focus on human problems (the artist's role, the social system, the language of art). The 1980s focused on the environmental impact of waste generation. The composition of the rubbish also plays an increasingly important role.

\footnotetext{
${ }^{2}$ Although plastic materials were already developed in the 19th century (cellulose was invented in 1855 by Alexander Parkes, polymerization of vinyl chloride in 1838-1872), the breakthrough was produced on a mass scale bakelite (1907, Leo Baekeland) and plastics from the second half of the 1920s.
} 
Plastic is a model material for artists due to its mass production and impossible removal from the environment. The philosophy of the new materialism of Graham Harman and Jane Bennett [17], Latour's Actor-Network theory, and the nature of culture by Donna Haraway is also influencing cultural reflection and artistic practices. An important function in constructing an artistic idea is through political ecology and recognizing competing environmental and social relation approaches [10]. It starts with Felix Guattari's question about the environment and new forms of subjectivization (mental, social and environmental). It determines the ethical and aesthetic attitude toward the world [8].

Cultural approaches help rethink human coexistence with other organisms and beings. While Donna Haraway's idea of natureculture has a holistic dimension and forces humans to include non-human species, the anthropocentric view is significant in Victor Margolin's reflection. The fear for the natural environment combines with humankind's chances of survival. According to the researcher, art-creation and design, inscribed in the postulate of cultural artificiality, must rethink its foundations. Margolin writes: "Among those heavily invested in replacing the natural with the artificial, resistance to this challenge is strong. And yet, as the artificial advances into the natural domain of our lives, we may partially lose our humanity" [4].

The above dilemmas are well represented by the examples of chosen artistic activities. Referring to the discussions from the mid-90s by Reiner Pilz and Rieman Verlag, the artists' approach to waste is changing and becoming more related to the awareness of the role of garbage in the natural environment. There is also a question about the treatment and recovery of substances from waste related to art. The terms related to artistic practices, used in scientific and industrial discourse, are recycling and upcycling. The first implies the recovery of useful substances from waste and sewage. The second indicates the increasing artistic, cultural, and economic value of this processed material.

Karolina Izdebska states: "Upcycling is not about processing the raw material, but processing it in a way that the resulting object has a higher value than its base object/material constituting the material" ([15], p.35). Thus, do we refer to recycling or upcycling when talking of the works by women artists based on plastic remnants? The analysis of works based on plastic debris makes us better understand these problems.

\subsection{The Objective of the Study}

This article indicates the relationship between artistic and social activities regarding environmental pollution with plastic waste

The primary objective is to:

1. Identify artistic strategies to generate awareness about pollution by analyzing the intentions of the artists, and the theoretical and social context of their works.

2. Characterize the cultural, social, and artistic goals of the authors through a detailed examination of the artwork components.

3. Familiarize audiences and professional scholars specializing in natural science with the achievements of contemporary artists.

\section{Results}

\subsection{Plasticus Progressus - Predicting the Future of the Earth}


The "Human-Free Earth" exhibition at the Ujazdowski Castle Centre for Contemporary Art in Warsaw in 2019 displayed an installation by Australian artist Bonita Ely entitled "Plasticus Progressus" (2017). This collection of plastic objects fills one of the rooms of the gallery (Figure 1). Plastic scraps cover the space, and there are posters on the walls presenting new species in an almost biological way. This installation language takes inspiration from the bricolage-like sitespecific art of the 1960s and 1970s. This is when environments composed of rubbish and dumps were created (e.g, "Twelve Hundred Coal Bags Suspended from the Ceiling over a Stove" by Marcel Duchamp from 1938, or "Yard" by Allan Kaprow from 1961). Bonita Ely's work is about presenting objects seemingly devoid of value with a carefully constructed narrative. Ely offers viewers a futuristic game, seasoned with a bitter commentary on the foundations of the world being created.

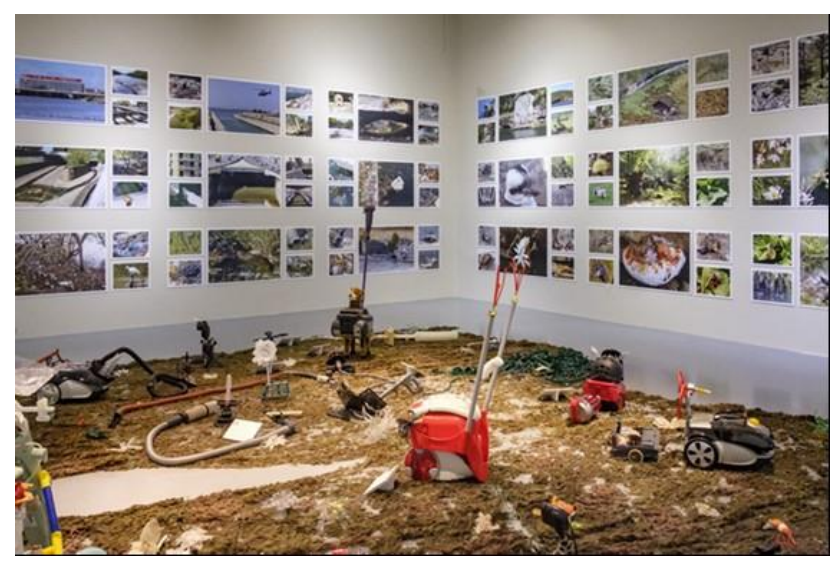

Figure 1 The view at the exhibition of Human Free-Earth in Ujazdowski Castle Centre for Contemporary Art, 2019, phot. Bartosz Górka (in the foreground Bonita Ely, Plasticus Progressus, 2017).

The artist used remnants of everyday objects like vacuum cleaners, children's toys, plastic bags, and bottles or pipes to create the show. They collected these from the rivers of three cities: Sydney, Athens, and Kassel. "Plasticus Progressus" is a story of the consequences of plastic waste dominance over the planet. But is it self-control or abandonment? According to Ely's interpretation, garbage will lead to the evolution of new species that resemble ocean animals and plants. They evolve not because they want to conquer the human world but are a byproduct of human activity. They emerged because they disappeared from human sight and gained independence.

The digital part of the project (http://plastikus.online) harmonizes with the spatial implementation in the gallery display. It broadens the knowledge about a brave new plastic world. Ely presents the evolution of new species on the website and analyzes river flows that distribute the garbage on their shores. It also shows images of ocean currents responsible for moving the plastic on the Earth's surface.

Hendrik Folkerts calls Ely's approach trans-ecological [11]. This trans-ecology includes the changes of all life forms and the inanimate world. Evolution concerns more than the world of living creatures described by Darwin. In the post-human world, life made of plastic waste will replace animals and plants. Ely writes: "These organisms have inter-bred and largely displaced the unfortunate animals that died by ingesting indigestible plastics as food. The plasticus creatures' 
competitive edge is their digestion/mobility system. They are colloquially called the "hoover maneuver", sucking up and thrusting through the 240,000 tonnes of plastic waste accumulated in ocean gyres, including our plastic litter polluting rivers, beaches, and human habitats" [18].

Ely equips this fantastic biology with a full theoretical background. She creates a new reality set in time and presents the genesis of her organisms. It begins in 1907, the year of Bakelite's invention, which culminates in 2054. The bacterial processing of plastic produces a new species, breathing, moving, and living.

Here, we have the "Hells Angel", derived from a vacuum cleaner (Figure 2). Ely adds a careful description of the behavior and functions of its various body parts. Its black protective shell resembles the Shogun headgear, with its tiny horn-shaped vodka bottle receptors that send low sound vibrations to the Hells Angel's eardrums. The legs of the reptile evolve into sound receptors. The Hells Angel has a long protruding tail where it digests and stores its diet of plastic flowers, similar to a fuel tank. Ironically, the females are usually larger than the males. It has a small brain with no hippocampus that anatomically enables behaviors like emotion, learning, memory, and spatial navigation. They may survive even after decapitation for up to 6 months [18].

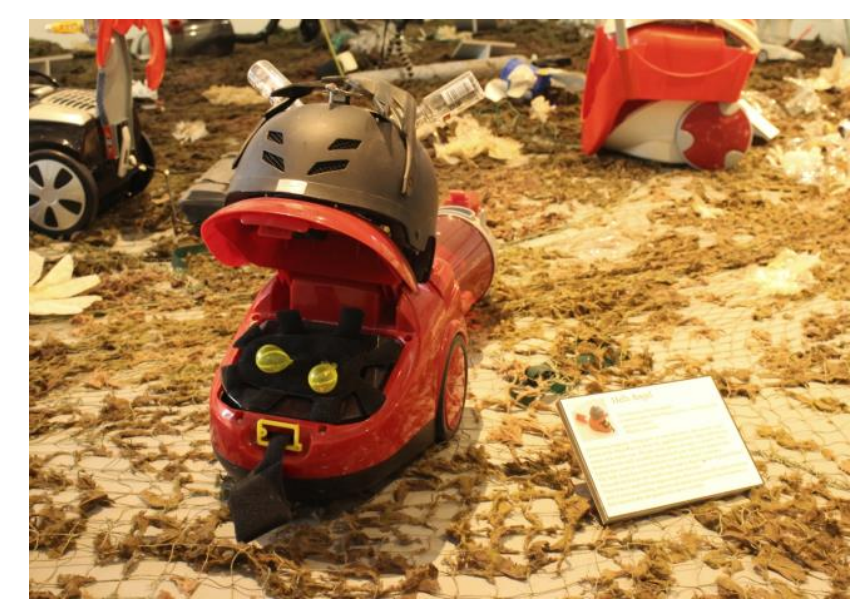

Figure 2 Bonita Ely, Hells Angel, 2017, the exhibition Human Free-Earth in Ujazdowski Castle Centre for Contemporary Art, 2019, phot. Marianna Michałowska.

In the Warsaw show version of the installation, Ely's project was a part of the curatorial project by Jarosław Lubiak. The title "Plasticity of the Planet" takes inspiration from the philosophy of Christine Malabou [19]. "Plastic progress" reflects the philosopher's ideas. Malabou's concept of destructive plasticity comes from the philosophy of Hegel and Heidegger. It means that thoughts (in the context of an exhibition-substance) deform and change the shapes of other thoughts/substances. The deformed, however, will not return to its original state [20]. This philosophy echoes in Bonita Ely's realization. Plastic is malleable, but its presence on Earth is inevitable. Its decomposition into microparticles will also not separate the existing contaminants. "Plasticus Progressus", expresses different imagery that envisions a world inevitably evolving with the products of man, self-organizing from abandoned organisms.

\subsection{Bounty, Pilfered - Discussing Social Consequences of Using Plastic:}

The work of the American artist Pam Longobardi is as impressive as Ely's installation. "Bounty, Pilfered" by Longobardi debuted in 2014 at the exhibition GYRE: The Plastic Ocean, curated by 
Julie Becker (Figure 3). It is an object in the form of a giant metal horn. The artist used steel found from the North Pacific coast to create it. It resembles a wreck overgrown with shells, and these shells are also artificially made of debris. The object is filled with derelicts and remnants of devices used in industrial fishing production. The artist and her colleagues collected the material for this overwhelming object/sculpture from the coasts of Alaska, Greece, Costa Rica, and the Gulf of Mexico. Buoys, broken nets, and plastic ropes spill from their dark form.

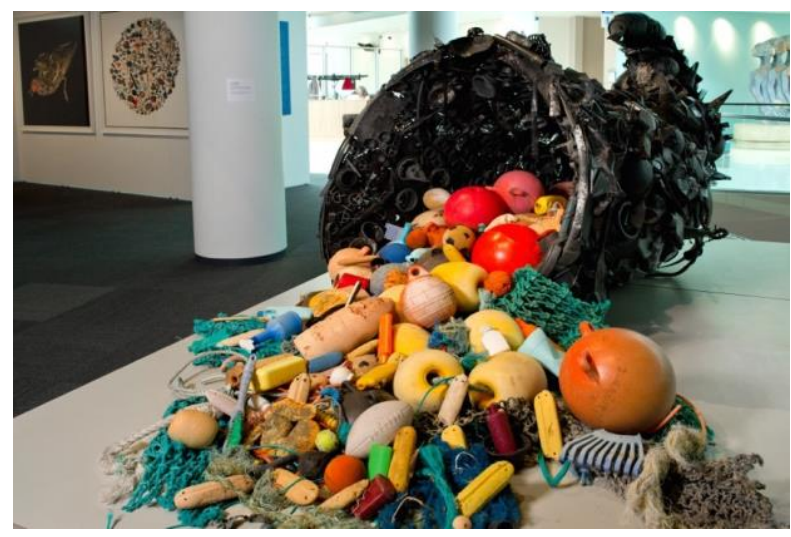

Figure 3 Pam Longobardi, Bounty, Pilfered, 2014, the exhibition GYRE: The Plastic Ocean, 2014, Photograph courtesy of the David J. Sencer CDC Museum. Available from: https://daily.jstor.org/artists-response-to-plastic-ocean-pollution/.

In the interview, the artist told Jeffrey C. Gleaner, "If plastic functions as a dark material, a shadow of humanity's repressed fears of horror vacuum and ego dissolution, it surely plays the role of a surrogate for human reach, exemplified by our endless quest for colonization and worldly creation" [21].

The artwork emphasizes the ambiguous condition of modern fishing in the contemporary economic and social discourse. Plastic makes fishing more convenient, provides millions of people with jobs and food. The usage of natural resources to produce ropes, buoys or nets leads to polluted seas and oceans. It poisons the sea creatures with microplastics or kills them in abandoned nets [21].

The title "Bounty" is therefore equivocal since it evokes the image of an ocean that is no longer an inexhaustible resource. Thus, humans pilfer the abundance of oceans. The wreckage and catastrophe, occurring in the seas and oceans, can also illustrate Gillian Whiteley's thesis that waste is a metaphor for postcolonial reality [13]. Overfishing in the sea and oceans illustrate the social inequalities and international conflicts. Economic and social issues related to the dynamic nature of local communities living off the catch are at its center. Above all is the uncovering of hidden problems that are invisible to wealthy consumers, demanding more of "seafood".

In Longobardi's work, her social commitment is instrumental. The artwork she presents summarizes the fieldwork executed with residents and activists. The Drifters Project, established by the artist in 2006, is an excellent manifestation of action through art. Longobardi combines the documentary exploration of coastal areas with a convincing investigation of social and cultural phenomena in her project. Such an example is a collaboration on the Greek island of Lesbos in 2016 where Longobardi documented thousands of life jackets abandoned on its coast and the remains of pontoons cut by smugglers to prevent incoming arrivals. In 2014, she initiated the 
"Plastic Free Island" project where she promotes beach and coast cleaning and joint creation of artworks with local women artists. They carried out similar actions on the island of Kefalonia in Greece and Armila, Panama. The artist is also the co-founder of an initiative, including artists, scientists, and social activists, entitled "The Conscious Ocean". It emphasizes the relationships and mutual influence of different regions of the world. Longobardi describes the project by saying "it is a ONE WORLD OCEAN, one continuous, flowing, an interconnected liquid entity" (https://driftersproject.net/about/).

\subsection{Crochet Coral Reefs - Replacing the Nature}

The third example of artistic reflection on the plastic pandemic is the work of Australian Margaret and Christine Wertheim. Margaret is an advocate of science and author of books on the cultural history of physics. Christine deals with critical theory. At the Venice Biennale in 2019, the artists displayed a "Crochet Coral Reef", resulting from activities established by the Margaret Wertheim Institute for Figuring (Figure 4). It is an organization promoting the aesthetic dimension of mathematical research.

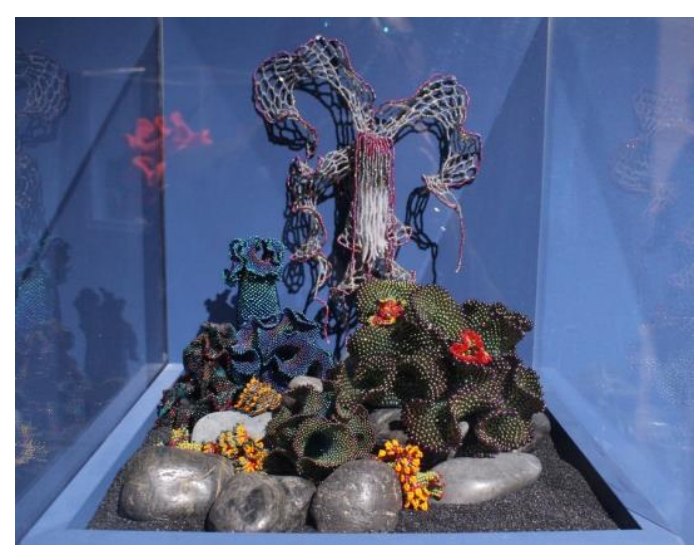

Figure 4 Margaret and Christine Wertheim, Crochet Coral Reef, from 2005, The 58th International Art Exhibition, titled May You Live In Interesting Times, The Venice Biennale, 2019, phot. Marianna Michałowska.

The forms that the artists displayed resemble valuable jewelry, and this effect gets enhanced by their display. They resemble jewelry showrooms, presented in glass cases and illuminated by the spotlight. The crocheted reef resulted from the collective action of over 10,000 participants worldwide. It uses beads, threads, fragments of rocks, and sand. Fragmentary experiments helped weave plastic fibers and other substances from waste into the reef structure. The work uses both new and found materials, unlike the previous examples.

Wertheim twins emphasize the interdisciplinary, scientific, and artistic nature of the project. It refers to the ecology, the endangered Great Barrier Reef, and the relationship between mathematics and the natural world. The structures crocheted by the artists display the mathematical aspects of reality. They are examples of a hyperbolic surface, characteristic of nonEuclidean geometry. ${ }^{3}$

\footnotetext{
${ }^{3}$ The ability to crochet such forms was discovered in 1997 by Daina Taimina, the mathematician from Cornell University.
} 
Crochet Coral Reefs extend the aesthetic potential of the artwork over the works of Ely and Longobardi. This is an aesthetic based on artificiality and replacement. The materials used for crocheting did not contain their original context and became a completely new creation. It is the result of artistic activity. We will not recognize the origin of the material in these fantastic structures, unlike Longobardi. The work also does not have the DIY nature of Ely's futuristic vision. The realization entices with colors and texture but is dead, like a natural coral reef. It has the aesthetics of melancholic entropy. Newly created realities emerge and react to environmental conditions, similar to organic coral reefs, despite this deadness. The colors fade when exposed to light, and delicate structures disintegrate with time. Since the reef growth results from the interaction of millions of microorganisms, their creation requires the cooperation of hundreds of people. The production of these structures is slow, and they grow attached. They are also a vision of the future where natural organisms will be replaced with artificial ones, similar to the Bonita Ely project.

\section{Discussion}

Issues discussed in the above-mentioned works define the specialty of the artists. These include an ecological crisis caused by global warming, environmental pollution, extinction of species, and overfishing of oceans and seas. Each of these projects can be a part of "environmental art", an artistic trend. We can trace its beginning to the neo-avant-garde art movements like Land Art or Art of the Object. Since the 1960s, the focus shifted to the political and social dimensions of the relation between art practices and nature. T.J. Demos characterizes this artistic movement [10] as an in-depth analysis of the political, economic, and social relationships and the understanding of the relationship between human behavior and its environmental effects. The works of Ely, Longobardi, and the Wertheim sisters do not assume any possibilities of sustainable development. It is impossible since this domination of waste, this "unwanted inheritance" of mankind (the term introduced by ecologic archeologist Thora Pettursdottir), is indisputable.

How to classify the description of the art practices, are they recycled or upcycled? The first concept, according to Izdebska, includes recovering materials to reduce the consumption of natural resources. The second sees the resulting object gain value related to its material. Upcycling is about getting creative with your material by turning it into a value for artwork object ([15], p.41).

The definition of each term may be different from others. Recycling is a process where used material returns to the production line (for example processing used glass into new bottles) and upcycling includes the production of originally unintended uses (like making a raft from plastic bottles).

These projects somewhat change what the rejected and worthless into a work of art, thus, meeting the assumptions of upcycling. They also completely transform the core of the processed debris. They get cleaned, assuming their extraction from their previous state of contamination. We cannot smell the sea scent of nets and ropes or the decomposing odor of a landfill or sewage. The raw material is refined. But what is the price of this upcycling?

These artworks fit interestingly with the discussions, whether the artistic production of art pieces is polluting the environment or is excessive production of artistic objects unnecessary for survival (from the economic perspective of objects). The aim of these projects goes far beyond the scope of creating another item for an art collection (I leave the question of whether the museum 
collections are not an example of a trash collection). None of the above-mentioned works answer how to counteract the plastic pandemic. So, what is the purpose of Ely, Longobardi, and Wertheim's works? Is their only purpose to multiply the discourse of the art world and be powerless against reality? Such a statement is unfair to their projects because art is not for providing practical solutions to the world, but for recognizing the existence and indicating possibilities. It is valid even if the possibility seems unrealistic in our reality.

\section{Conclusions}

The artists' recognition of the dominating waste in the environment and the necessity to include it in their activities is prophetic. Initially, garbage, junk, and debris represented the nascent modernity- affirmatively and critically. Today, they illustrate its decline. Plastic is a symptomatic material, and it perfectly embodies the dilemmas of modern times. It expresses the economic aspects world, impacts the lives of local communities, and transforms the living environment of fauna and flora. They become part of the "dark ecology", written by Timothy Morton. He believes that humanity cannot fake unawareness of its relationship with the natural environment [5, 22]. Plastic waste represents that part of the dark ecology called hyperobjects. Morton writes that "Hyperobjects do not rot in our lifetimes. They do not burn without themselves burning (releasing radiation, dioxins, etc.). The ecological thought must consider the future of these objects. These toxic objects appear more realistic than reality, like the acidic blood of the Alien in Ridley Scott's film, burning through metal floors"([23], p.130).

These increasing artistic projects whose basic raw material is plastic, suggest that artists are focusing on the exhaustion of natural materials. The self-consciousness of its creators requires further research. We could conduct interviews with the artists, for example, on their perception of their role in the process of art production or their attitude toward archiving their projects.

Three basic functions of artistic practices in environmental art emerge by analyzing the meanings of these objects and the artistic intentions behind them. The role of these described projects is:

1) To initiate discussions about the effects of plastic overproduction.

2) To create a community that is aware of the processes in the seas and oceans.

3) To engage the attention of local communities on their members and ecological problems that have microscale solutions through several participatory activities (it is most noticeable in the initiatives of Longobardi and Margaret Wertheim).

Significantly, that the mentioned works were created by women artists. It includes some features of eco-feminism in environmental art.

These art practices indicate the inevitability of dark ecology. Plastic debris is not scrapped anymore but a readily available material for art. Its use is an artistic extravagance and is a necessity. The mentioned artworks are ecological because they do not destroy the remaining natural resources. Instead, they use what is unnecessary and harmful. Above all, they expand the horizon of art without detaching it from our reality. It, at all costs, remains close to reporting the catastrophe that occurred in our lifetime.

\section{Acknowledgments}


The author would like to thank her colleagues from the Institute of Cultural Studies of the AMU for inspiring and broadening the area of the discussed issues remarks and comments and Ujazdowski Castle Centre for Contemporary Art in Warsaw for providing visual materials.

\section{Author Contributions}

The author did all the research work of this study.

\section{Funding}

The study was financed by the research fund of the Institute of Cultural Studies of Adam Mickiewicz University in Poznań, Poland.

\section{Competing Interests}

The author has declared that no competing interests exist.

\section{References}

1. Thevenon F, Carroll C, Sousa J. Plastic debris in the ocean: The characterization of marine plastics and their environmental impacts, situation analysis report. Gland, Switzerland: IUCN; 2014; 52.

2. Highmore B. Walter Benjamin's trash aesthetics. In: Everyday life and cultural theory: An introduction. London: Routledge; 2001.

3. Lozinski-Veach N. Decompositions: Inheriting trash with Walter Benjamin and Bruno Schulz. MLN. 2018; 133: 763-792.

4. Margolin V. The politics of the artificial: Essays on design and design studies. Chicago: The University of Chicago Press; 2002.

5. Morton T. Being ecological. Cambridge, Mass: The MIT Press; 2018.

6. Jadzinska M, Parzuchowski P. New materials in works of art (plastics) - the challenge of our times. Synergy in the field of recognition, damage, assessment and protection. Proceedings of the International Conference on Cultural Heritage; 2014 November 3-8; Limassol, Cyprus.

7. Whiteley G. Situating junk: Art, garbage and trash ontologies. In: Design, waste \& dignity. Săo Paulo: Editora Olhares; 2014.

8. Brunner C, Nigro R, Raunig G. Post-media activism, social ecology and eco-art. Third Text. 2013; 27: 10-16.

9. Cucuzzella C. Making the invisible visible: Eco-art and design against the anthropocene. Sustainability. 2021; 13: 3747.

10. Demos TJ. Contemporary art and the politics of ecology. Third Text. 2013; 27: 1-9.

11. Folkerts H. Bonita Ely [Internet]. Available from: https://www.documenta14.de/en/artists/1001/bonita-ely.

12. Breaking the plastic wave: A comprehensive assessment of pathways towards stopping ocean plastic pollution [Internet]. One Planet; 2020. Available from: https://www.oneplanetnetwork.org/.

13. Bakke M. Pandemiczne wspólnoty przenoszone drogą plastikową. In: Pandemia. Nauka, sztuka, geopolityka. Poznań-Szczecin: Akademia Sztuki w Szczecinie; 2018. 
14. Benjamin W. The arcades project. Cambridge: Harvard University Press; 1999.

15. Izdebska K. Lepsze życie śmieci? Desing i upcycling. Kultura Popularna. 2017; 2: 31-40.

16. Markowska A. Sztuka śmieci i polityka odpadów. Quart. 2012; 3: 87-95.

17. Bennett J. Vibrant matter. A political ecology of things. Durham, North Carolina: Duke University Press; 2010.

18. Ely B. Plasticus progressus [Internet]. Available from: http://plastikus.online.

19. Lubiak J. Human-Free Earth. Curatorial text in exhibition catalogue. Warsaw: CSW Zamek Ujazdowski, $2017 \quad$ [Internet]. Available from: jazdowski.pl/en/programme/exhibitions/bezludzka-ziemia?tid=przewodnik.

20. Malabou C. The ontology of the accident: An essay on destructive plasticity. Cambridge: Polity; 2012.

21. Jeffery C. Pam Longobardi: The ocean gleaner [Internet]. Drain Magazine; 2016. Available from: http://drainmag.com/pam-longobardi-the-ocean-gleaner/.

22. Morton T. The ecological thought. Cambridge, Mass: Harvard University Press; 2010.

23. Morton T. Hyperobjects: Philosophy and ecology after the end of the world. Minneapolis: The University of Minnesota Press; 2013.

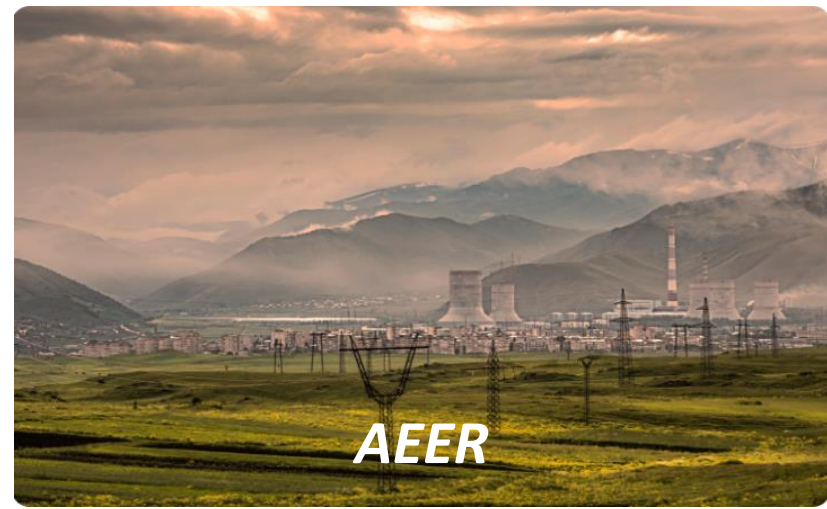

Enjoy AEER by:

1. Submitting a manuscript

2. Joining in volunteer reviewer bank

3. Joining Editorial Board

4. Guest editing a special issue

For more details, please visit:

http://www.lidsen.com/journals/aeer 